\title{
Primary intracerebral lymphoma: Case report
}

\author{
Primer intraserebral lenfoma: Olgu sunumu
}

\author{
Olcay Eser ${ }^{1}$, Önder Şahin ${ }^{2}$, Serhat Korkmaz ${ }^{1}$, M. Gazi Boyacı ${ }^{1}$
}

\begin{abstract}
We describe a case of primary central nervous lymphoma (PCNSL) that may be confused with magnetic resonance imaging (MRI) findings of high grade glioma. Primary central nervous lymphoma is a rare tumour and it account for $0.3-3 \%$ of intracranial tumours. A 61 year's old woman was admitted to our clinic with a severe headache, vomiting, left hemiparesia and transient loss of consciousness. Primary central nervous lymphoma may show various biological and radiological characteristics. We herein emphasized being confused with MRI findings of PCNSL and high grade glioma. J Clin Exp Invest 2012; 3 (3): 409-411
\end{abstract}

Key words: Primary central nervous lymphoma, high grade glioma, B-cell, diagnosis

\section{INTRODUCTION}

Primary central nervous system lymphoma (PCNSL) is by definition an extranodal lymphoma beginning in the central nervous system (CNS) in the lack of systemic disease. It's a high grade Non-Hodging's lymphoma. ${ }^{3,4}$ It's almost B-cell type..$^{3,4,5,11}$ It account for $0.3-3 \%$ of intracranial tumours. ${ }^{2}$ PCNSL has higher incidence in parents with immunodeficient status and high prevalence is organ transplants. ${ }^{5,8}$ This patient was a high grade glioma similar to PNCSL lack a immunodeficiency.

\section{CASE}

A 61 year's old woman was admitted to our clinic with a severe headache, vomiting, left hemiparesia $(3 / 5)$ and transient lost of consciousness. There was a right frontal lobed $30 \times 25 \mathrm{~mm}$.enhanced and large diffuse edema lesion on MRI (Fig 1). Radiological report was a glial tumour (Fig 2). The patient was operated a frontal craniotomy and the lesion was a extract gross totally. Dexamethasone were

\section{ÖZET}

Burada magnetic rezonans görüntüleme (MRG) bulguları ile yüksek dereceli glioma ile karışabilecek olan bir primer merkezi sinir sistemi lenfoması (PMSL) sunuyoruz. Primer merkezi sinir sistemi lenfoması nadir bir tümördür ve intracranial tümörlerin \% 0.3-3'ünü oluşturur. Altmış bir yaşında kadın hasta kliniğimize ciddi baş ağrısı, kusma, sol hemiparezi ve geçici bilinç kaybı ile getirildi. Primer merkezi sinir sistemi lenfoması çeşitli biyolojik ve radyolojik özellikler gösterebilir. Burada PMSL'nin MRG bulgularının yüksek dereceli glioma ile karışmasını vurguladık.

Anahtar kelimeler: Primer merkezi sinir sistemi lenfoması, yüksek dereceli glioma, B-hücre, tanı

given $16 \mathrm{mg} /$ day preoperative and postoperative. The histopathological examination revealed diffuse atypical lymphocyte cell infiltration, B-cell lymphoma. There were no pathological findings on abdominal, thoracic and bone marrow investigations. Serology for HIV and Ebstain Bar virus were normal. She had no history of immunodeficent. The patient was discharged on the postoperative 7 day without any problem. One month after the surgery followup MRI. Patient was referred the oncology center to chemotherapy and radiotherapy. Pathological examination revealed a atypical lymphocyte and diffuse atypical B cell (Fig 3). Immunohistochemical were studied GFAB, EMA, CD3, CD20 and cytoceratin. CD20 positif revealed a specific antibody for B-cell lymphocytes in tumour cell membranes (Fig 3). GFAB, EMA, CD3 and cytoceratin was negative. These pathological features were compatible with B-cell type non-hodging lymphoma. The patient was discharged on the postoperative 7 day without any problem. The patient was referred to the onchology center for radiotherapy and chemotherapy.

${ }^{1}$ Department of Neurosurgery, Faculty of Medicine, Afyon Kocatepe University, Afyon, Turkey

${ }^{2}$ Istanbul University, Institute for Experimental Medical Research, Istanbul, Turkey

Correspondence: Olcay Eser,

Dept. Neurosurgery, Kocatepe University, Faculty of Medicine, Afyonkarahisar/Turkey Email: drolcayeser@hotmail.com Received: 10.05.2012, Accepted: 13.06.2012

Copyright (C) JCEI / Journal of Clinical and Experimental Investigations 2012, All rights reserved 


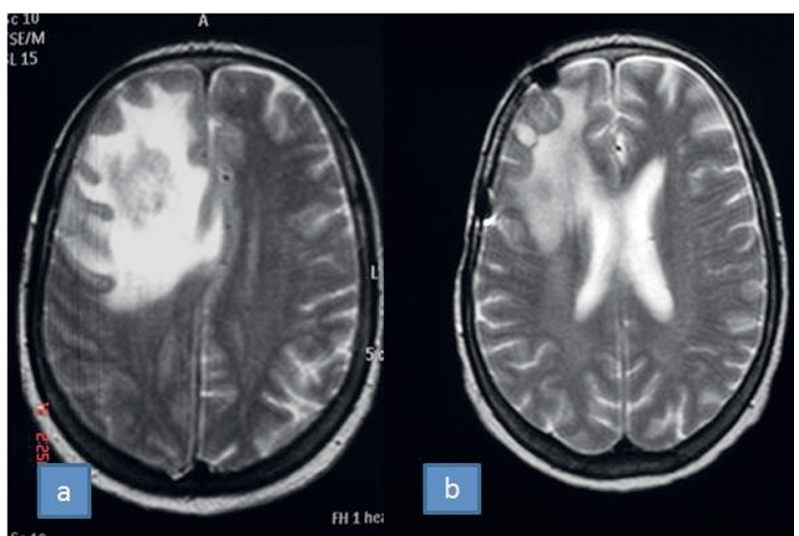

Figure 1. a) Preoperative T2-weighted MR images showing a solid, enhanced tumor edema in the right frontal lobed, b) Postoperative T2-weighted MR image.

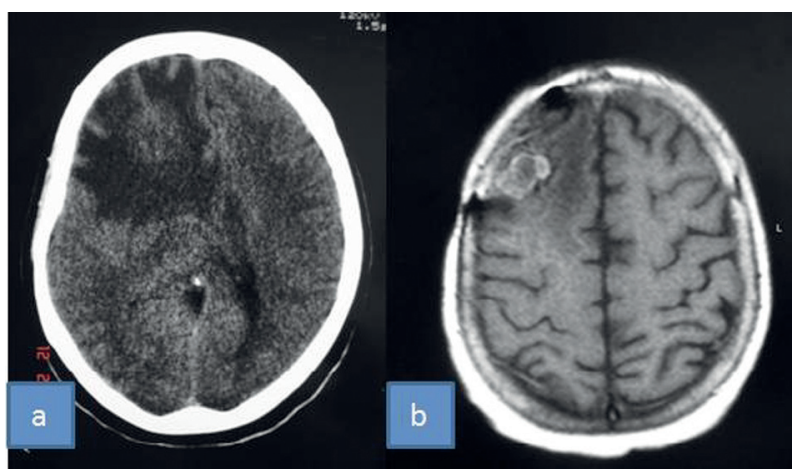

Figure 2. a) Preoperative Cranial CT images showing a solid, enhanced tumor edema in the right frontal lobed, b) Postoperative T1-weighted MR images.

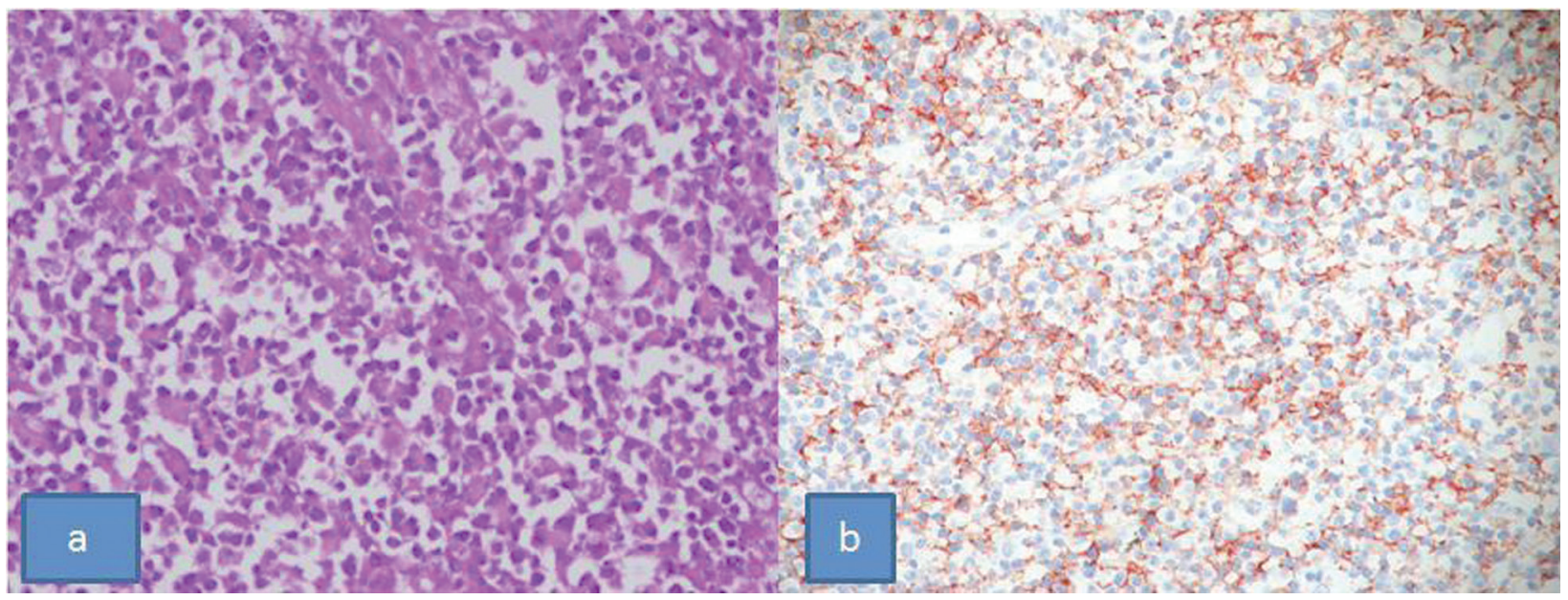

Figure 3. a) The tumor cells demonstrates a population of mitotically active medium-to-large-sized lymphoid cells. (H,E X200). b) shows immunoreactivity for CD20 in the tumor cells (immunoperoxidase/ABC, X200).

\section{DISCUSSION}

Primary CNS lymphomas with other primary brain tumours are extremely rare. Primary central nervous system lymphoma present with neurological sings and sysmtoms related to the location. These diseases often present with similar sings and symtoms; lack distinguishing features based on clinical history, physical examination, and MRI; and often show nonspesific changes in the cerebrospinal fluid (CSF). The commonest presenting symptoms in were mental status changes $44 \%$ and hemiparesis $31 \% .{ }^{1}$ We made diagnosis a malingnant glioma with clinical findings and MRI.

Primary central nervous system lymphoma exemplify a disease that may share radiological, clinical, and laboratory that similar to many CNS diseases such as malignant gliomas, metastases and inflammatory diseases.7,8,9,12 The differential diagnosis of PCNSL includes glioma, metastasis, pseudo tumoural multiple sclerosis, brain abscess, subacute infarct, neurosarcoidosis, langerhans histocytosis, CNS infection (cytomegalovirus, toxoplasmosis, etc.). ${ }^{8,9,10,11}$

CT and MRI imaging studies due to its hypercellularity, high nuclear/cytoplasmic ratio. Masses most commonly appear isodense or hyperdense on CT scans and enhance homogeneously after intravenous administration of contrast material. ${ }^{8,9,10} \mathrm{MRI}$ showed the lesion as marked hyperintense on heterogeneous-weighted and edema on the images, which was compatible with a gliomas. Lymphomas are generally hyperintense on diffusion-weighted imaging consistent with water restriction due to high cellularity, but the solid lesion appeared as hypoin- 
tensity. Because the specimen of the solid tumour consisted of lymphoma cells and extensive necrosis, the atypical finding by diffusion-weighted imaging was probably due to such extensive necrosis. ${ }^{8,9}$

The typical PCNSL seen in immunocompotent individuals presents as a supratentorial, deep-seated, generally solitary mass $65 \%$. The most common locations are the frontal lobe, basal ganglia and corpus callosum. The lesion tend to be large $(>2 \mathrm{~cm})$ and vary in circumscription. ${ }^{11}$ The lesions are more often located in the frontal $20 \%$, parietal $18 \%$, temporal lobes $15 \%$, and occipital lobes $4 \%{ }^{8}$ The vast majority of lesions were supratentorial; approximately $60 \%$ were deeply located; $25 \%$ of patients presented multipl lesions. Lymphoma was mentioned on the radiological repot as the most likely or one of the possible diagnoses in $57 \%$ of cases. ${ }^{7}$ And this case MRI revealed right frontal lobed mass $30 \times 25 \mathrm{~mm}$. enhanced heterojen and intensely after contrast injection.

The histopathological diagnosis is malingnant B cell lymphomas in $98 \%$ of cases of PCSNL. The tumour contains perivascular $B$ cells expressing pan B-cell marker such as CD19, CD20 or CD79a. ${ }^{10}$ And analysis of paraffin-embedded tissue is performed using the following stains and antibodies: hematoxylin and eosin, glial fibrillary acidic protein (a marker for glial neoplasms), CD3 (a T-cell marker), CD20 (a B-cell marker), CD45 (a common leukocyte antigen, which stains both $T$ and $B$ cells), and keratin (a marker for carcinoma). These studies solidify the the diagnosis of PCNSL and may furher categorize the tumour based on immunological cell surface. ${ }^{12}$

Immunodeficiency is associated with an increased risk of primary CNS lymphoma. Nearly all primary CNS lymphomas in immunodeficient patients are associated with EBV or HIV infections. . $^{1,5,6,7,7,9,910}$ Although our patient was did not have any of the clinical symptoms that would suggest immunodeficiency.

\section{REFERENCES}

1. Dubuisson A, Kaschten B, Lénelle J. Primary central nervous system lymphoma: Report of 32 cases and review of the literature. Clin Neurol Neurosurg 2004;107(1):55-63.

2. Günaydin A, Er U, Acuduman A, Sabuncuoğlu H. Diagnostic and surgical pitfalls of an unusual primary central nervous system lymphoma. Turk Neurosurg 2007;17(2):129-33.

3. Bessell EM, Hoang-Xuan K, Ferreri AJ. Primary central nervous system lymphoma biological aspects and controversies in management. Eur $\mathrm{J}$ Cancer 2007;43(7):1141-52.

4. Roser F, Saini M, Meliss R. Apoptosis, vascularity, and proliferation in primary central nervous system lymphomas (PCNSL): a histopathological study. Surg Neurol 2004;62(5):393-9

5. Bellinzona M, Roser F, Ostertag $\mathrm{H}$. Surgical removal of primary central nervous system lymphomas (PCNSL) presenting as space occupying lesions: a series of 33 cases. Eur J Surg Oncol 2005;31(1):100-5.

6. Masuoka J, Sakata S, Maeda K. Adjacent epidermoid cyst and primary central nervous system lymphoma: case report. Surg Neurol 2008;69(5):530-3

7. Ng S, Butzkueven H, Kalnins R. Prolonged interval between sentinel pseudotumoral demyelination and development of primary CNS lymphoma. J Clin Neurosci 2007;14(11):1126-9

8. Eichler AF, Batchelor TT. Primary Central Nervous System Lymphoma: Presentation, Diagnosis, and Staging. Neurosurg Focus. 2006:15;21(5):E15.

9. Hunt MA, Jahnke K, Murillo TP. Distinguishing primary central nervous system lymphoma from other central nervous system diseases: a neurosurgical perspective on diagnostic dilemmas and approaches. Neurosurg Focus 2006:15;21(5):E3.

10. Hochberg NFH, Baehring JM, Hochberg EP. Primary CNS lymphoma. Neurosurg Focus 2006:21(5):543-4.

11. Commins DL. Pathology of primary central nervous system lymphoma. Neurosurg Focus 2006:15;21(5):E2.

12. Elder JB, Chen TC. Surgical interventions for primary central nervous system lymphoma. Neurosurg Focus 2006:15;21(5):E13. 